\title{
Panegiryczne i antyrewolucyjne niemieckie dramaty mieszczańskie XIX wieku
}

Ewa Jurczyk 
nAP7S Seria VII 2001

\section{Ewa Jurczyk}

\section{Panegiryczne i antyrewolucyjne niemieckie dramaty mieszczańskie XIX wieku}

$\mathrm{W}$ ybuch rewolucji francuskiej intelektualiści niemieccy powitali z wielkim entuzjazmem i zarazem zazdrością, ponieważ naród francuski dokonał rzeczy niemożliwej do przeprowadzenia w rozbitych i nieskonsolidowanych Niemczech. Po przejęciu władzy przez jakobinów większość pisarzy niemieckich przeżyła szok, który odbił się szerokim echem w życiu kulturalnym księstw niemieckich. Wielcy pisarze i myśliciele zdystansowali się do rewolucji, chwaląc jej idee, potępiając jednak jej metody, część intelektualistów zamilkła, większość — przede wszystkim dramatopisarze - uciekła w literaturę popularną.

Dramaturdzy tacy jak: August Wilhelm von Kotzebue (1761-1819), August Wilhelm von Iffland (1759-1814), Joseph Marius Babo (1756-1822), Julius de Soden (1754-1831), Friedrich Ludwig Schroeder (1741-1816) czy Friedrich Wilhelm Ziegler (1759-1827) tematem swoich sztuk uczynili życie rodzinne mieszczaństwa niemieckiego. Pisali dramaty, w których wykorzystywali motywy literatury niemieckiego oświecenia i okresu Burzy i Naporu, spłaszczając je i pozbawiając wymowy politycznej, uwypuklając za to aspekt moralny. Unikali ostrzejszego rysowania konfliktów, akcję konsekwentnie prowadzili do szczęśliwego zakończenia (pogodzenia skłóconych członków rodziny, ślubu lub rehabilitacji podejrzanego o korupcję lub zdradę urzędnika). W nielicznych dramatach, których akcja wychodziła poza dom i życie rodzinne, jednoznacznie opowiadali się przeciwko rewolucji i innym siłowym formom obalania władzy, ponieważ uważali, że silny książę, cesarz czy król jest gwarantem stabilizacji.

Postać władcy w strywializowanym dramacie mieszczańskim końca XVIII i początku XIX wieku jest projekcją zdroworozsądkowych poglądów mieszczaństwa niemieckiego. Rozbite na ponad 300 księstw Niemcy miały ponad trzystu absolutnych władców. Rozbicie spowodowało nie tylko osłabienie ekonomiczne państwa, skłócenie poszczególnych księstw, powstanie ambicji separatystycznych (na przykład w Bawarii), niemożliwość przeprowadzenia jakichkolwiek reform, lecz 
przede wszystkim nieopisany rozrost administracji państwowej. A administracja pracowała w prawie każdym księstwie inaczej, urzędnik był przekupny, nieuczciwy, niesolidny, często niewykształcony, a więc niekompetentny. Uczciwy, solidny, pracowity, bogacący się mieszczanin niemiecki marzył o stabilizacji, pewności jutra i bezpieczeństwie. Gwarantem takiego stanu miał być jeden zdecydowany i silny władca ${ }^{1}$.

Bardzo rzadko akcja dramatów mieszczańskich ocierała się o rewolucję, rewoltę czy chociażby poważniejsze rozruchy. Przeważały dramaty, w których poprzez odpowiednie prowadzenie postaci władcy gloryfikowane były: dyscyplina, podporządkowanie i posłuszeństwo. Akcja toczyła się na dwóch zazębiających się płaszczyznach — prywatnej i państwowej, co umożliwiało porównanie panującego księcia, króla czy cara z innym władcą — ojcem rodziny. Najistotniejszą wspólną cechą obu panujących było to, że nie podlegali krytyce ${ }^{2}$.

Powodów takiego prowadzenia postaci władcy kraju (Landesvater) i władcy domu (Hausvater) należy szukać w sentymentalnym kulcie rodziny. W dramacie mieszczańskim XVIII wieku panowała tendencja uwznioślania stosunków zależności i gloryfikowania autorytetu. Stosunek zależności dziecka od rodzica został przeniesiony na płaszczyznę religijną i państwową: Bóg był czułym Ojcem Ludzi, Książę dobrotliwym Ojcem Poddanych. Władca domu, czyli ojciec rodziny odpowiedzialny był przed Bogiem za los powierzonej mu rodziny, władca kraju, czyli ojciec narodu za los powierzonych mu przez Boga poddanych. Do umocnienia tej tendencji przyczynił się socjolog Joseph Sintenis, głoszący teorię, że rodzina jest pomniejszoną kopią państwa. Ojciec był głową rodziny, władca głową państwa; ojciec sprawował opiekę nad dziećmi oraz żoną, władca nad poddanymi; jedynie ojciec wiedział, co jest dla rodziny dobre i jedynie on mógł ją uszczęśliwić; podobnie władca postępował w stosunku do swoich poddanych. Punktem wyjścia takiego układu zależności było ubezwłasnowolnienie rodziny i poddanych, czyli założenie, że naród (mężczyźni, kobiety i dzieci) oraz rodzina (kobiety i dzieci) są zbyt ograniczone (mówiono wprost: głupie), aby podejmować jakiekolwiek decyzje; rodzina ojca rodziny (władcy domu) i poddani ojca narodu (władcy kraju) powinni uznać mądrość Ojca i Władcy, jego autorytet, akceptować bez szemrania jego plany, a do tego wszystkiego jeszcze go chwalić i kochać. Miłość do władcy ograniczała się jedynie do jego osoby i nie oznaczała miłości do państwa. Państwo, a właściwie aparat państwowy reprezentowany przez urzędników, był czymś bezdusznym (według Lessinga czymś „abstrakcyjnym”) i barierą uniemożliwiającą bezpośredni kontakt z Władcą-Ojcem ${ }^{3}$. Dlatego wymienieni dramatopisarze ukazywali księcia czy króla jako władcę dobrego, ale niedoinformowanego lub oszukanego przez swoich doradców lub urzędników, co powodowało, że poddani często widzieli w nim władcę niesprawiedliwego lub okrutnego. Doradca zawsze pochodził z bogatej rodziny arystokratycznej i wykorzystywał swoją pozycję dla prywat-

1 Zob. D. Maurer, August von Kotzebue. Ursachen seines Erfolges. Konstatnte Elemente der unterhaltenden Dramatik, Bonn 1979 , s. 280.

${ }^{2}$ Zob. H. Möller, Die Kleinbürgerliche Familie im 18. Jahrhundert. Verhalten und Gruppenkultur, Berlin 1969, s. 23.

3 Zob. L. Pikulik, „Bürgerliches Trauerspiel” und Empfindsamkeit, Köln-Wien 1981, s. 148; zob. tez: J. Hoffmann, Die „Hausväterliteratur" und die „Predigten über den christlichen Hausstand”, Mannheim-Berlin 1959, s. 73. 
nych celów - wzbogacenia się lub umocnienia swoich wpływów. Na bohatera dramatu wyrastał niepozorny, skromny urzędnik-mieszczanin, który demaskowal wysokiego urzędnika, odkrywal jego oszustwa i ukazywał poddanym prawdziwe oblicze władcy. Książę lub król wynagradzał niższego rangą urzędnika, karał przykładnie zdrajcę, który „pozbawił go miłości ludu” i obiecywał, że już nigdy nikt "nie zdoła staną́ między nim a [jego] ludem”. Postacie były schematyczne (władca szlachetny, arystokrata zły i podstępny, mieszczanin uczciwy), akcja prowadzona zawsze według tego samego schematu:

— skorumpowany urzędnik (oficer) intryguje przeciwko władcy;

— władca karze niewinnego urzędnika (oficera);

— poddani wątpią w sprawiedliwość władcy;

- niewinny urzędnik (oficer) zostaje zrehabilitowany;

— poddani przekonują się o szlachetności władcy.

Aby uatrakcyjnić dramat, autorzy wprowadzali wątek miłosny. Młoda cnotliwa panna na wydaniu, którą ojciec chce wydać za przekupnego urzędnika (bo to lepsza partia), kocha skromnego urzędnika, który dla ojca jest nic nieznaczącym gryzipiórkiem. Pod koniec dramatu nie tylko władca przekonuje się do walorów niedocenionego współpracownika, lecz także nieprzejednany ojciec. Aby ostatecznie przekonać ojca, wladca wynagradza wiernego urzędnika awansem lub znaczną nagrodą pieniężną. Czasami to władca znajduje upodobanie w jednej ze swoich poddanych, lecz w zakończeniu dramatu unosi się ponad siebie - rezygnuje z prywatnego szczęścia i poświęca się dla swoich poddanych, zezwalając na ślub panny ze swoim oficerem lub urzędnikiem.

W nielicznych dramatach, w których w tle mają miejsce bliżej niesprecyzowane rozruchy zwane przez bohaterów rewolucją, z rewoltą konfrontowany jest zarówno ojciec rodziny, jak i ojciec kraju. Władca gasi w zarodku plany wystąpienia przeciwko władzy i przekonuje, że poddani nie mogą sami decydować o swoim losie, ponieważ są niedojrzali i nie wiedzą, co jest dla nich dobre. Tylko władca jako oświecony pomazaniec boży jest w stanie ocenić, co uszczęśliwi jego poddanych. Ojciec (władca rodziny) cierpi poważniejsze męki. W rozruchach biorą udział nieposłuszni, niesforni synowie, którzy nie są w stanie ocenić bezmiaru szkód wyrządzonych przez nieposłuszeństwo. Bo pójście na barykady to dla ojca rodziny młodzieńczy wybryk, bunt przeciwko władzy ojca lub niezrozumienie jego planów dotyczących przyszłości rodziny. Podobnie jak władca, ojciec wie najlepiej, co uszczęśliwi synów, ma dokładnie sprecyzowane plany dotyczące ich życia. Ojcowie nie interpretują rewolucji w kategoriach państwowych czy wolnościowych, lecz jako wyraz klęski metod wychowawczych: ojciec zawiódł jako władca-głowa rodziny 5 .

Jeżeli dramatopisarz przedstawia rewolucje, tak jak na przykład Iffland w Kokardach ${ }^{6}$, to rebelia mieszczan i chłopów pragnących na wzór francuski zastąpić system feudalny bezpośrednią władzą ludu,

\footnotetext{
${ }^{4}$ Zob. F. W. Ziegler, Der Lorbeerkranz, oder Die Macht der Gesetze, Wien 1799, akt V, sc. 4 (wszystkie thumaczenia w artykule - E. J.).

${ }_{5}^{5}$ Zob. E. Jurczyk, Das Drama von August Wilhelm Iffland als Atsdruck des Identitätsproblems des deutschen Bürgers, „Studia Germanica Posnaniensia", t. 19, 1993, s. 72.

${ }^{6}$ Zob. A. W. Iffland, Die Kokarden, Leipzig 1802.
} 
jawi się jako przestępstwo przeciwko naturalnemu porządkowi. Jako taka musi upaść: nie dlatego, że zostaje zduszona przez wojska księcia (bliżej nieokreślonego), lecz dlatego, że rebelianci sami uznają swój błąd i winę. Po wtargnięciu do pałacu nie zabijają władcy, nie odbierają mu władzy. Skruszony przywódca mówi w uniesieniu do swoich towarzyszy (akt V, sc. 3):

Chodźcie — wszyscy — złóżcie kokardy u stóp uczciwego władcy.

A kiedy rebelianci to czynią, zwraca się do księcia:

Tak, łaskawy Panie — Niech Bóg nam przebaczy, że zakłóciliśmy Księciu spokój.

Widząc kokardy, symbole rewolucji pod butami księcia, chłopi wznoszą okrzyki radości. Przyjmują także na siebie winę za zniszczenia dokonane w mieście w czasie rozruchów. Nie pojmują prawidłowości mówiącej, że system oparty na przemocy można obalić jedynie przemocą, i pokornie słuchają oskarżeń księcia:

Dobrym, spokojnym mieszczanom spaliliście domy nad głowami - czy to jest wolność? Zrabowaliście cudzą własność - czy to jest wolność? Zabiliście starców, zranili nieletnich i wrzucili do ognia wielu ludzi — czy to jest wolność?

Słuchając wyrzutów księcia, ci prości ludzie przestają widzieć w nim władcę, a zaczynają poznawać dobrotliwego ojca kraju, za którego rządów podobne wydarzenia nie miały miejsca ${ }^{7}$. Dzieci były nieposłuszne, dobry ojciec przekonuje, że to, przeciwko czemu usiłowali walczyć pańszczyzna, dziesięcina, ubezwłasnowolnienie - jest darem ojca kraju dla dzieci i wyrazem jego troski o nie. Ponieważ dzieci zbłądziły, ojciec nie ukarał ich, lecz wytłumaczył:

Kto wam mówi, że wasz stan można uwolnić od mozolu, ten pozbawia was zbawienia i przeczy porządkowi bożemu. - Czegóż chcecie? Żyć bez Pana? W takim wypadku bardzo szybko staniecie się bandą zbójców.

Ponieważ rebelianci nie potrafili się odnaleźć w wywalczonej na krótko wolności, z wdzięcznością przyjmują decyzję władcy; znalazł się ktoś, kto wiedział, co należy uczynić, kto za nich pomyślał i podjął decyzję. Książę odsyła ich do domu, a byli powstańcy przyrzekają:

Wrócimy teraz do naszych domów - a po drodze szczerze wyznamy, do czego doprowadziła nas nędza wolności!

Akcja dramatu rozgrywa się tradycyjnie na dwóch płaszczyznach — oprócz państwowej jest jeszcze rodzinna. Syn i córka tajnego radcy księcia przyłączają się do powstańców. W wypadku syna rebelia polityczna jest traktowana jako bunt przeciwko patriarchalnej strukturze rodziny.

7 Zob. H. A. Glaser, Das bürgerliche Rührstück, Stuttgart 1969, s. 48. 
Autorytet i wychowanie są jednak silniejsze niż bunt, ponieważ syn postawiony wobec wyboru decyduje się zdradzić idee rewolucji i uratować życie ojca.

O ile bunt syna tajny radca był w stanie zaakceptować, to przyłączenie się córki do rebelii jest dla niego sprzeczne z naturą — ojciec nazywa córkę „istotą wynaturzoną” (akt II, sc. 2). Dla młodej kobiety przyłączenie się do rewolucji to pierwszy krok w kierunku emancypacji jej płci. Córka ośmiela się mówić o „prawach obywatelki” (akt II, sc. 5). Ojciec nie jest zaszokowany czynem córki, lecz obrażony, ponieważ jak wszyscy ojcowie przyzwyczajony był do „wdzięcznego posłuszeństwa” córki, do tego, że „kobieta powtarza jak modlitwę to, co się jej podpowie”. Autorytet ojca rodziny i ojca kraju jest prawem naturalnym, ponieważ obydwaj otrzymali władzę od Boga, rewolucja jest naruszeniem naturalnego porządku rodziny i państwa. Młodzi buntujący się przeciwko władzy ojca i władzy księcia nigdy nie będą dobrymi, to znaczy posłusznymi obywatelami ${ }^{9}$.

Potępienie rewolucji ma także uzasadnienie materialne. Zamieszki w mieście zawsze powodowały zniszczenia, a straty ponosili przede wszystkim przez pokolenia bogacący się mieszczanie. W dramacie Ifflanda kupcy walczyli razem z chłopami do momentu, w którym miało dojść do podziału dóbr materialnych. Kiedy walczący o wolność mieszczanie zorientowali się, co wolność oznacza dla chłopów, zawarli pokój z księciem.

Także w dramacie Buntstrzelców ${ }^{10}$ w tle pojawia się powstanie. Autor Joseph Marius Babo, koncentrując akcję sztuki wokół skutków pierwszego powstania strzelców i przygotowań do drugiego, gloryfikuje konsekwentną i brutalną politykę cara Piotra Wielkiego. W tym wypadku wladcą nie jest abstrakcyjny, nienazwany książę niemiecki, lecz konkretnie określona postać historyczna. Car w interpretacji Babo jest władcą absolutnym, czasami bardzo okrutnym, ale zarazem i ojcem narodu, dla którego szczęście ,jego Rosjan” (akt I, sc. 4) jest dobrem najwyższym. Podobnie jak Iffland, Babo łączy płaszczyznę prywatną z państwową: pułkownik strzelców Ossakow, przywódca pierwszego powstania, został przez cara ułaskawiony, to znaczy zesłany na Syberię; jego wychowywany przez popów syn zostaje przez podwładnych ojca wybrany na przywódcę drugiego powstania.

Powstanie strzelców Piotr traktuje jak wybryk niemądrych, nieoświeconych dzieci, które nie wiedzą, co dla nich dobre. Car poświęca się dla nich, nie śpi po nocach, czasami „traci cierpliwość”, ale wie, że jest ojcem „swoich Rosjan”, więc musi zacisnąć zęby i wykazać się „anielską cierpliwością, żeby nie posłać ich do wszystkich diabłów”. Car nie wierzy w rozwój ludzkości, uważa, że człowiek potrzebował i nadal potrzebuje silnej ręki nad sobą (akt II, sc. 1). Piotr Wielki zamiast argumentów wolał użyć siły, ponieważ naród był bez polotu, zbyt prymitywny i nierozgarnięty, aby zrozumieć plany władcy. Ponieważ wszystko, co car z miłości do narodu robił dla swojego ludu, było interpretowane jako przemoc i samowola władcy, car doszedł do wniosku, że musi rządzić silną ręka, jako że rozsądne argumenty do nieoświeconego ludu i tak nie trafią. Troską o dobro i przyszłość narodu usprawiedliwia samowolę, okrucieństwo, niesprawiedliwość, zabójstwa i kaźnie. Car uważa, że posłuszny jest tylko ten, który się lęka. Na płaszczyźnie

\footnotetext{
${ }^{8}$ Zob. H. Möller, op. cit., s. 75.

9 Zob. M. Krause, Das Trivialdrama der Goethezeit 1780-1805, Bonn 1982, s. 319.

11) Zob. J. M. Babo, Die Strelitzen, Berlin 1793.
} 
państwowej Piotr Wielki Josepha Babo działa brutalniej niż anonimowy książę Ifflanda — dzięki donosowi wiernego służącego odkrywa plany strzelców i krwawo tłumi zaplanowaną rebelię, ponieważ ich bunt oznacza według niego zniszczenie kraju ${ }^{11}$.

Babo próbuje przekonać widza o słuszności polityki Piotra Wielkiego oraz usprawiedliwić jego brutalność. W tym celu uczłowieczył go, odkrywając przed widzem słabostkę cara - jego próżność, która sprawiała, że marzył o miłości i uznaniu swoich poddanych. W czasie rozmowy z Marią Ossakow, żoną pułkownika strzelców, car zorientował się, że jego rządy są zbyt rygorystyczne i brutalne. Maria przekonała go, że jeżeli za najmniejsze wykroczenie groziła kara śmierci, człowiek stawał się niebezpieczny, ponieważ przestawał się bać, zaczynało mu być obojętne, czy umrze za drobne wykroczenie, czy za udział w powstaniu (akt II, sc. 5). Dlatego na płaszczyźnie prywatnej car Josepha Bobo zachowuje się jak dobrotliwy ojciec — nie dość, że nie skazał na śmierć przywódcy pierwszej rebelii, to jeszcze sprowadził go, w tajemnicy przed rodziną, z Syberii do Moskwy, a występującemu przeciwko władzy cara synowi darował życie. Uszczęśliwiona Maria prowadzi swoich mężczyzn na plac kaźni ich towarzyszy i żąda od męża i syna, by głośno wychwalali dobroć i lagodność cara (akt IV, sc. 9):

Chodźcie wszyscy i pomóżcie mi dziękować, pomóżcie wołać ludowi: niech żyje nasz Car i Ojciec!

Ułaskawienie syna sprawiło, że stary pułkownik i jego żona z zagorzałych przeciwników stali się gorącymi zwolennikami Piotra.

Epizod z rodziną Ossakowów przekonał Piotra Wielkiego, że łaską uzyska więcej. Musiała to jednak być łaska odpowiednio dozowana. Strzelcy zostali straceni, bo działali świadomie, młody Ossakow jako „zaślepiony” i „błądzący” został ułaskawiony.

Car z pewnym żalem wydał wyrok śmierci na strzelców, ponieważ była to formacja stworzona przez niego, jego żołnierze, których podziwiał za odwagę, męstwo i waleczność (akt II, sc. 3):

Dzielni byli, ci niepokorni; ale teraz w armii ważniejsze jest posłuszeństwo niż odwaga.

Skazując ich na śmierć, pokazał narodowi, że nie sentymenty, lecz racja stanu kierują jego zachowaniem. Strzelcy byli zagrożeniem dla Rosji, dlatego car musiał zniszczyć swoich najlepszych żołnierzy.

Sami strzelcy uważają się za szlachetnych i prawych, ponieważ walczą przeciwko tyranowi, za jakiego uważają Piotra (akt II, sc. 1).

W sztuce tej, takjak we wszystkich tego rodzaju, rzuca się w oczy natrętny dydaktyzm. Poddani mogą wybierać: jeżeli zbuntują się przeciwko władzy, czeka ich śmierć; ci, którzy w odpowiednim

$"$ Zob. E. Jurczyk, Die Rolle des deutschen historischen Dramas für das Fortbestehen der polnischen Biihne. Exemplifiziert durch Josef Marius Babos „Strelitzen”, w: Studien zur deutschen Sprache und Literatur, red. Z. Mielczarck, Katowicc 1994, s. 82 . 
momencie nawrócą się i uznają konieczność absolutnej władzy nad sobą, zostaną wynagrodzeni, to znaczy będą mogli dalej żyć.

Osobna grupę sztuk stanowią te, w których bunt przeciwko władzy nie jest związany z rebelią poddanych, ma więc raczej charakter prywatny. Pikanterii dodaje im fakt, że buntującym się jest syn władcy. Panujący książę lub król traktuje swych synów o wiele ostrzej i okazuje im mniej pobłażania niż zwykłemu buntującemu się poddanemu. Młody książę we wspomnianym wyżej dramacie Zieglera Wieniec laurowy (Der Lorbeerkranz) zainteresował się córką swojego pułkownika i nie chciał uznać władzy książęcego oficera nad sobą; infant Hiszpanii, Don Pedro z dramatu historycznego Inez de Castro Juliusa de Soden ${ }^{12}$ chciał poślubić matkę swoich trzech synów, a nie wyznaczoną mu przez ojca księżniczkę. Obydwaj ojcowie nie wahają się krytykować swoich synów w obecności służby i wymagają absolutnego podporządkowania się ich woli. Książę akceptuje osadzenie przez pułkownika krnąbrnego syna w areszcie, żądając, by młody książę nauczył się subordynacji. Ojciec uważa, że jako młody kształcący się oficer jego syn podlega woli i jurysdykcji pułkownika, i w takim wypadku książęca krew jest bez znaczenia. Przyszły władca powinien się nauczyć dyscypliny, subordynacji i posłuszeństwa, ponieważ jedynie ten, kto sam jest $\mathrm{w}$ stanie słuchać, będzie miał posłuch u innych ${ }^{13}$. Młody książę buntuje się, ale uznaje rację stanu, i aby udowodnić poddanym, że dobro państwa jest dla niego ważniejsze niż uczucie, rezygnuje nawet z miłości do córki pułkownika.

Mniej optymistycznie kończy się bunt infanta portugalskiego w Inez de Castro. Ponieważ Don Pedro nie potrafi zrezygnować z miłości do Inez i uważa ponadto, że zamiar poślubienia konkubiny świadczy o jego uczciwości wobec poddanych, król każe zgładzić kochankę syna. Ubolewa nad tym, ale racja stanu jest dla niego ważniejsza niż sentymenty czy uczucie własnego dziecka. Don Pedro odchodzi z dworu ojca i przysięga zemstę.

W tej grupie dramatów autorzy tak prowadzą postaci władców, aby pokazać ich moralną wielkość. Książę lub król jest człowiekiem szlachetnym, aktywnym, obowiązkowym, odpowiedzialnym za losy poddanych i niezależnym. Szlachetność, aktywność, obowiązkowość, odpowiedzialność za rodzinę i niezależność były także ideałami mieszczaństwa niemieckiego. Zrównanie władcy z poddanym na płaszczyźnie moralnej powodowało, że widz zapominał o społecznym pochodzeniu księcia czy króla, widząc w nim jedynie ideał niemieckiego mieszczanina, tak zwanego „uczciwego człowieka” (den ehrlichen Mann). Po usunięciu wszystkich przeszkód skorumpowany urzędnik zostanie zdemaskowany, błądzący lud przekonany o niesłuszności swojego postępowania, buntujący się następca tronu uleczony z egoizmu - widz uznaje system społeczno-polityczny za rozsądny i akceptuje go — przecież władca to taki sam „uczciwy człowiek" jak on sam, więc bunt nie ma sensu ${ }^{14}$.

Krytycy ubolewali nad poziomem dramatów tworzonych przez wymienionych autorów, twierdząc, że ich twórczość jest dowodem upadku kultury niemieckiej, że dramaturdzy ci

12 Zob. J. de Soden, Inez de Castro, Lcipzig 1802.

${ }_{13}$ Zob. M. Horkheimer, Studien iiber Autorität und Familie, Paris 1936, s. 49.

${ }_{14}$ Zob. M. Krause, op. cit., s. 240. 
zniszczyli gust literacki Niemców. Publiczność teatralna nie przejmowała się krytykami i tłumnie odwiedzała teatry wystawiające popularne dramaty mieszczańskie. Jedynie Goethe przyznawal, że Kotzebue i jego koledzy mają talent teatralny, że są mistrzami w operowaniu nastrojem, w ukazywaniu siermiężnej czasami — codzienności oraz marzeń i pragnień przeciętnego widza.

Konserwatywne w swej wymowie dramaty popularnych dramaturgów niemieckich nie psuły gustu widza, nie miały zgubnego wpływu na niego, nie usypiały społeczeństwa niemieckiego, były jedynie odzwierciedleniem myśli, obaw i pragnień przeciętnego mieszczanina, dla którego rewolucja oznaczała - jak sformułował to Schiller w Pieśni o dzwonie - straty materialne, niepotrzebny rozlew krwi i upadek moralności.

Dramaty te stanowiły ważny punkt w repertuarze każdego teatru. Ponieważ scena zależna była od pieniędzy sponsora, którym przeważnie był książę, należało zdobyć przychylność władcy. Dlatego większość dyrektorów scen, zżymając się na poziom „tych sztuczydeł”, często sięgała po nie, aby pochlebstwami i peanami na cześć władcy zdobyć fundusze na dalszą egzystencję lub aby uśpić czujność cenzury, od której często zależał byt teatru. 